\title{
PERENCANAAN KURIKULUM DI SMP NEGERI 3 SINGKAWANG
}

\author{
Andar Suhanda, Asri Budiningsih \\ Program Studi Manajemen Pendidikan PPs UNY, UNY \\ andar.suhanda@gmail.com
}

\begin{abstract}
Abstrak
Penelitian ini bertujuan untuk mendeskripsikan bagaimana SMP Negeri 3 Singkawang merencanakan kurikulum dari pemerintah agar sesuai dengan karakteristik sekolah, perencanaan komponen-komponen kurikulum di SMP Negeri 3 Singkawang, faktor-faktor penghambat dalam perencanaan kurikulum, usaha sekolah dalam mengatasi hambatan serta keunggulan SMP Negeri 3 Singkawang dalam perencanaan kurikulum. Penelitian ini menggunakan metode kualitatif. Pengumpulan data dilakukan melalui wawancara, observasi serta pencermatan dokumen. Keabsahan data dilakukan dengan wawancara mendalam serta triangulasi data melalui sumber dan metode. Hasil penelitian menunjukkan bahwa perencanaan kurikulum dilakukan oleh tim pengembang kurikulum. Hambatan dalam perencanaan kurikulum adalah kekurangpahaman guru terutama guru senior dalam mengintrepetasikan kurukulum sesuai pedoman-pedoman dari pemerintah. Usaha sekolah untuk mengatasi hambatan dalam perencanaan kurikulum adalah mengadakan in house training secara khususnya, mengadakan workshop dengan mendatangkan narasumber dari LPMP provinsi. Keunggulan-keunggulan SMP Negeri 3 Singkawang dalam perencanaan kurikulum antara lain: a) analisis lingkungan strategis; b) analisis pendidikan saat ini dan masa depan; c) program strategis dan strategi pelaksanaan/pencapaian; d) penambahan jam pelajaran; e) program remidial dan pengayaan; f) kegiatan pengembangan diri.
\end{abstract}

Kata kunci: perencanaan, kurikulum

\section{CURRICULUM PLANNING IN SMP NEGERI 3 SINGKAWANG}

\begin{abstract}
This study aimed to describe how SMP Negeri 3 Singkawang planned the curriculum by the government to conform to the characteristics of the school, the inhibiting factors in the curriculum planning, the school's effort in overcoming obstacles and the privilege of SMP Negeri 3 Singkawang in curriculum planning. This study used qualitative methods. Data were collected through interviews, observation and document scrutiny. Data validation was done by in-depth interviews and triangulation of data through sources and methods. The results show that curriculum planning is done by a team of developers of the curriculum. Obstacles in the planning of the curriculum are lack of understanding of teachers, especially senior teachers in interpreting appropriate guidelines from the government. School efforts to overcome the obstacles in the planning of the curriculum is to conduct in-house training in particular, hold a workshop and to bring in speakers from the province LPMP. The privileges of SMP Negeri 3 Singkawang in curriculum planning, among others: a. strategic environmental analysis, $b$. education analysis of current and future, c. strategic programs and implementation strategies or achievement, $d$. the addition lesson hours, e. remedial and enrichment programs, and f. personal development activities
\end{abstract}

Keywords: planning, curriculum 


\section{Pendahuluan}

Rencana pemerintah untuk melakukan penggantian Kurikulum Tingkat Satuan Pendidikan di tahun 2013 mengindikasikan bahwa KTSP merupakan kurikulum yang sudah tidak relevan lagi dengan tuntutan perkembangan zaman. KTSP memberikan otonomi yang luas kepada satuan pendidikan untuk bertanggung jawab mengembangkan kurikulum sesuai dengan kondisi satuan pendidikan setempat dengan memperhatikan keunggulan lokal serta memperhatikan kepentingan pendidikan nasional yang berwawasan global dianggap belum maksimal dalam mewujudkan peningkatan kualitas pendidikan sehingga pemerintah berupaya melakukan perubahan KTSP di tahun 2013.

SMP Negeri 3 Singkawang menjadi sekolah menengah pertama yang merupakan sekolah prioritas bagi orang tua siswa untuk mendaftarkan anak-anak mereka di SMP Negeri 3 Singkawang dibandingkan dengan sekolah-sekolah menengah pertama lainnya di kota Singkawang. Bagi orang tua siswa, ada kebanggaan tersendiri apabila anak mereka bisa bersekolah di SMP Negeri 3 Singkawang. Semua data tesebut diperoleh penulis pada saat melakukan prasurvei pada bulan Agustus 2012.

Dengan visi “Menuju Sekolah Berprestasi yang Berwawasan Global Berdasarkan Iman dan Takwa“, SMP Negeri 3 Singkawang telah berhasil meraih berbagai prestasi di berbagai bidang, baik bidang akademik, maupun bidang nonakademik. SMP Negeri 3 Singkawang tidak hanya berprestasi di kota Singkawang dan propinsi Kalimantan Barat saja, namun juga di tingkat Nasional. Berbagai prestasi yang telah dicapai oleh SMP Negeri 3 Singkawang antara lain: Juara 1 Olimpiade Nasional Sains, Biologi, Fisika tahun 2010, peringkat 1 UN dari tahun 2005-2012 se kota Singkawang, juara 1 Porseni kota Singkawang pada tahun 2009,2010, juara 2 Porseni Kalimantan Barat tahun 2010, serta sejumlah prestasi-prestasi lainnya.

Pada tahun ajaran 2009-2010, SMP

Negeri 3 Singkawang ditetapkan oleh pe- merintah sebagai satu-satunya SMP di Kota singkawang yang mendapat predikat Rintisan Sekolah Bertaraf Internasional dan merupakan sekolah yang kedua di tingkat propinsi Kalimantan Barat setelah SMP Negeri 3 Pontianak. Pada tanggal 12 Desember 2009, SMP Negeri 3 Singkawang ditetapkan sebagai sekolah dengan akreditasi A dengan nilai akreditasi 94, oleh Badan Akreditasi Nasional Sekolah/Madrasah.

Berbagai prestasi yang berhasil dicapai oleh SMP Negeri 3 Singkawang disebabkan oleh berbagai komponen pendidikan yang berfungsi dengan maksimal. Komponen-komponen pendidikan yang mendukung berbagai prestasi yang dihasilkan oleh SMP Negeri 3 Singkawang antara lain guru, sarana dan prasarana dan kurikulum. Kurikulum sebagai salah satu komponen pendidikan yang mendukung berbagai prestasi yang dihasilkan oleh SMP Negeri 3 Singkawang merupakan pedoman mendasar dalam proses belajar mengajar di dunia pendidikan.

Menurut Oemar Hamalik (2008:65), kurikulum adalah program pendidikan yang disediakan oleh lembaga pendidikan (sekolah) bagi siswa. Berdasarkan program pendidikan tersebut, siswa melakukan berbagai kegiatan belajar sehingga mendorong pertumbuhan dan perkembangannya sesuai dengan tujuan pendidikan yang telah ditetapkan. Dengan kata lain, sekolah menyedikan lingkungan pendidikan bagi siswa untuk berkembang dan kurikulum disusun sedemikian rupa oleh sekolah untuk memungkinkan siswa melakukan kegiatan pembelajaran.

Kegiatan-kegiatan kurikulum tidak terbatas dalam ruang kelas saja, melainkan mencakup juga kegiatan-kegiatan di luar kelas. Tidak ada pemisahan yang tegas antara intra dan ekstra kurikulum. Semua kegiatan yang memberikan pengalaman belajar/pendidikan bagi siswa pada hakikatnya adalah kurikulum.

Menurut Muhammad Nuh (2013:1): "sebagai sistem perencanaan pembelajaran yang baik, kurikulum harus mencakup empat hal. Pertama sebagai 
hasil akhir pendidikan yang harus dicapai peserta didik (keluaran). Kedua, kandungan materi yang harus diajarkan kepada, dan dipelajari oleh peserta didik (masukan/standar isi). Ketiga, pelaksanaan pembelajaran (proses, termasuk metodologi pembelajaran sebagai bagian dari standar proses). Keempat, penilaian kesesuaian proses dan ketercapaian tujuan pembelajaran sedini mungkin untuk memastikan bahwa masukan, proses, dan keluaran tersebut sesuai dengan rencana."

Mengingat pentingnya kurikulum dalam pendidikan, maka perencanaan kurikulum harus dilakukan dengan baik. Perencanaan kurikulum membutuhkan landasan-landasan yang kuat, yang didasarkan pada hasil-hasil pemikiran dan penelitian yang mendalam. Perencanaan kurikulum yang tidak didasarkan pada landasan yang kuat mengakibatkan kegagalan dalam mencapai tujuan pendidikan.

Penelitian ini berpedoman dari fakta berbagai prestasi dan keberhasilan SMP Negeri 3 Singkawang menjadi sekolah unggulan di kota Singkawang khususnya, yang merupakan cerminan keberhasilan pelaksanaan KTSP, dimana di tahun 2013 KTSP akan diubah oleh pemerintah karena dianggap kurang maksimal dalam meningkatkan kualitas pendidikan. Penelitian ini juga akan mendeskripsikan hal-hal khusus yang menjadi keunggulan di SMP Negeri 3 Singkawang dalam kegiatan perencanaan kurikulum sekolah sehingga diperoleh informasi yang lebih mendalam tentang perencanaan kurikulum di SMP Negeri 3 Singkawang. Selanjutnya dengan mengetahui perencanaan kurikulum di SMP Negeri 3 Singkawang, sekolah menengah pertama lain di kota Singkawang khususnya dapat belajar dari SMP Negeri 3 Singkawang dalam perencanaan kurikulum sehingga dapat menyelenggarakan pendidikan yang berkualitas dan menjadi sekolah yang memiliki daya tarik dan berprestasi.

Abdullah (2011:61-65) mengemukakan bahwa sebagai tahap awal dalam pengembangan kurikulum, perencanaan kurikulum meliputi tiga kegiatan, yaitu: perencanaan strategis (strategic planning), perencanaan program (program planning) dan perencanaan kegiatan pembelajaran (program delivery plans).

Menurut Oemar Hamalik (2006: 155-156) perencanaan kurikulum disusun berdasarkan asas objektivitas, keterpaduan, manfaat, kesesuaian, keseimbangan, kemudahan, berkesinambungan, pembakuan, mutu.

Oemar Hamalik (2006: 154-155) mengemukakan bahwa suatu perencanaan kurikulum memiliki sifat strategis, komprehensif, integratif, realistik, humanistik, futuralistik, merupakan bagian integral yang mendukung manajemen pendidikan secara sistematik, mengacu pada pengembangan kompetensi sesuai dengan standar nasional, berdiversifikasi untuk melayani keragaman peserta didik, desentralistik.

Menurut Buku Panduan Penyusunan Kurikulum Tingkat Satuan Pendidikan Jenjang Pendidikan Dasar dan Menengah (2006: 5-7) KTSP dikembangkan berdasarkan prinsip-prinsip sebagai berikut: Berpusat pada potensi, perkembangan, kebutuhan, dan kepentingan peserta didik, beragam dan terpadu, tanggap terhadap perkembangan ilmu pengetahuan, teknologi dan seni, relevan dengan kebutuhan kehidupan, menyeluruh dan berkesinambungan belajar sepanjang hayat, seimbang antara kepentingan nasional dan kepentingan daerah.

KTSP disusun dengan memperhatikan hal-hal sebagai berikut: Peningkatan iman dan takwa serta akhlak mulia, Peningkatan potensi, kecerdasan, dan minat sesuai dengan tingkat perkembangan dan kemampuan peserta didik, Keragaman potensi dan karakteristik daerah dan lingkungan, Tuntutan pembangunan daerah dan nasional, Tuntutan dunia kerja, Perkembangan ilmu pengetahuan, teknologi dan seni, Agama, Dinamika perkembangan global, Persatuan nasional dan nilai-nilai kebangsaan, Kondisi sosial budaya masyarakat setempat, Kesetaraan jender, Karakteristik satuan pendidikan. 


\section{Metode Penelitian}

Jenis Penelitian

Jenis penelitian yang digunakan oleh peneliti sangat menentukan hasil penelitian yang akan diperoleh. Penggunaan jenis penelitian yang tepat dalam suatu penelitian akan menghasilkan temuan penelitian yang sesuai dengan fokus penelitian. Fokus penelitian ini adalah untuk mendeskripsikan perencanaan kurikulum di SMP Negeri 3 Singkawang. Jenis penelitian yang tepat untuk mendeskripsikan perencananaan kurikulum di SMP Negeri 3 Singkawang adalah penelitian kualitatif.

\section{Pendekatan Penelitian}

Pendekatan penelitian yang digunakan dalam penelitian ini adalah pendekatan deskriptif. Pendekatan ini digunakan karena fokus dan tujuan yang hendak dicapai dalam penelitian ini adalah menggambarkan dan memperoleh pemahaman tentang fakta perencanaan kurikulum di SMP Negeri 3 Singkawang dilaksanakan.

\section{Subjek Penelitian}

Dalam penelitian ini, subjek penelitian ditentukan dengan menggunakan teknik purposive sampling dan snowball sampling. Dalam penelitian ini, yang menjadi fokus penelitian adalah perencanaan kurikulum di SMP Negeri 3 Singkawang, oleh karena itu subjek penelitian dalam penelitian ini adalah kepala sekolah, wakil kepala sekolah, waka kurikulum, guru mata pelajaran bahasa inggris, matematika, biologi, TIK, serta ketua komite sekolah.

\section{Teknik Pengumpulan Data}

Teknik pengumpulan data dalam penelitian ini menggunakan teknik wawancara dan dokumentasi serta observasi. Wawancara digunakan untuk memperoleh data secara lebih mendalam tentang perencanaan kurikulum di SMP Negeri 3 Singkawang.
Instrumen Pengumpulan Data

Sesuai dengan teknik pengumpulan data di atas, maka instrumen pengumpulan data dalam penelitian ini adalah pedoman wawancara, dokumentasi, serta observasi.

\section{Teknik Keabsahan Data}

Pada penelitian ini, untuk menjaga kredibilitas data, peneliti menggunakan teknik triangulasi. Teknik triangulasi dilakukan dengan menggunakan triangulasi sumber dan teknik.

\section{Teknik Analisis Data}

Menurut Miles \& Huberman (1985: 21-23) aktivitas dalam analisis data, yaitu data reduction, data display dan conclusion drawing/verification.

\section{Data reduction/reduksi data}

Reduksi adalah kegiatan memilih, menyeleksi, menentukan fokus, menyederhanakan dan mentransformasikan data yang diperoleh di lapangan. Data yang diperoleh di lapangan, baik dari hasil observasi, wawancara maupun pencermatan dokumen dirangkum dan dipilih sesuai dengan fokus penelitian kemudian disusun secara sistematis sehingga memberikan gambaran yang jelas tentang hasil penelitian.

\section{Data Display/penyajian data}

Penyajian data adalah menyusun sekumpulan data berdasarkan pola pikir, pendapat, dan kriteria tertentu untuk menarik kesimpulan. Penyajian data membantu untuk memahami peristiwa dan apa yang harus dilakukan untuk analisa data lebih jauh dan lebih dalam berdasarkan pemahaman terhadap peristiwa tersebut. Hal ini akan memudahkan peneliti dalam memahami hubungan atau gambaran terhadap aspek-aspek yang diteliti.

Conclusing drawing/verification/penarikan kesimpulan

Penarikan kesimpulan adalah menafsirkan data yang telah disajikan ber- 
dasarkan kategori yang ada serta menggabungkan data hasil temuan di lapangan dengan cara melihat hubungan semua data tersebut sehingga dapat diperoleh informasi tentang perencanaan kurikulum di SMP Negeri 3 Singkawang.

Analisis data dalam penelitian kualitatif bersifat induktif dimana proses analisis data dilakukan pada saat pengumpulan data berlangsung dan setelah pengumpulan data. Setiap data yang diperoleh dalam penelitian ini, dianalisis sesuai dengan tahapan-tahapan analisis data guna memperoleh kesimpulan sementara. Selanjutnya kesimpulan sementara tersebut diuji kembali nilai validitasnya selama penelitian berlangsung dengan melihat seluruh aspek rasionalitas, keakuratan serta keobjektifannya sampai diperoleh kesimpulan akhir sebagai jawaban atas pertanyaan penelitian.

\section{Hasil Penelitian dan Pembahasan}

Merencanakan Kurikulum dari Pemerintah

Berdasarkan hasil wawancara dengan kepala sekolah SMP Negeri 3 Singkawang, langkah pertama yang dilakukan oleh sekolah dalam melakukan perencanaan kurikulum adalah dengan melihat serta mempelajari panduan penyusunan kurikulum yang telah ditetapkan oleh Kementerian Pendidikan Nasional. Selanjutnya pihak sekolah mengadakan pertemuan dewan guru sekaligus melakukan pembentukan tim pengembang kurikulum.

Pembentukan tim pengembang kurikulum dilakukan di setiap awal tahun ajaran, diawal semester. Tim pengembang kurikulum mengalami perubahan sesuai kinerja mereka berdasarkan penilaian dari kepala sekolah. Apabila kinerja mereka baik, mereka akan terus menjadi anggota tim pengembang kurikulum, apabila kinerja mereka kurang maksimal, akan dilaksanakan pergantian oleh kepala sekolah. Kepala sekolah memiliki wewenang penuh untuk mengganti dan mempertahankan anggota tim pengembang kurikulum.
Pendapat kepala sekolah tersebut didukung oleh Waka Kurikulum SMP Negeri 3 Singkawang. Berdasarkan hasil wawancara dengan Waka Kurikulum SMP Negeri 3 Singkawang, langkah perencanaan kurikulum yang dilakukan oleh SMP Negeri 3 Singkawang dimulai dari mengadakan pertemuan dewan guru untuk menetapkan perencanaan kurikulum.

Pertemuan dewan guru SMP Negeri 3 Singkawang dilaksanakan setiap akhir tahun ajaran, bersamaan dengan rapat akhir semester. Selanjutnya dalam pertemuan tersebut, sekolah melakukan pembentukan tim pengembang kurikulum sekolah. Dalam pertemuan ini, semua guru SMP Negeri 3 Singkawang dilibatkan.

Tim pengembang kurikulum memiliki struktur organisasi, yang terdiri dari ketua, sekretaris serta anggota. Mereka dipilih berdasarkan bidang mata pelajaran masing-masing yang mereka ajarkan di sekolah. Mereka dipilih secara langsung oleh kepala sekolah berdasarkan kinerja mereka selama proses belajar mengajar serta berdasarkan mata pelajaran yang mereka ajarkan di sekolah. Tim pengembang kurikulum bertugas untuk mengembangkan serta melakukan evaluasi terhadap perencanaan pembelajaran yang telah dibuat oleh guru untuk dilaksanakan di tahun pelajaran berikutnya.

Pendapat kepala sekolah dan waka kurikulum tersebut diperkuat dengan adanya dokumen Surat Keputusan kepala sekolah SMP Negeri 3 Singkawang yang menyatakan untuk optimalisasi pelaksanaan program kerja bidang kurikulum di SMP Negeri 3 Singkawang, dibentuklah tim pengembang kurikulum SMP Negeri 3 Singkawang. Nama-nama anggota tim pengembang kurikulum SMP Negeri 3 Singkawang, disajikan pada Tabel 1. 
Tabel 1. Tim Pengembang Kurikulum SMP Negeri 3 Singkawang

\begin{tabular}{|c|c|}
\hline Nama & Jabatan \\
\hline Marselinus, SH. S.Pd. M.Si & Penanggung Jawab \\
\hline H. Bachtiar Usman, SmHk & $\begin{array}{l}\text { Ketua Komite } \\
\text { Sekolah }\end{array}$ \\
\hline Sovia & Ketua \\
\hline Fransiskus Andut, S.Kom & Sekretaris \\
\hline Hj. Slamet Yuniati & Anggota \\
\hline Teddy Isnanda, M.Pd & Anggota \\
\hline Guntur, S.Kom & Anggota \\
\hline Fitri Kurniati, S.Pd. I & Anggota \\
\hline Sumarni, S.Pd. I & Anggota \\
\hline Ida Haryati, A.Md. Pd & Anggota \\
\hline
\end{tabular}

Perencanaan Komponen-Komponen Kurikulum

\section{Merumuskan Sasaran dan Tujuan Kurikulum}

Berdasarkan hasil wawancara dengan kepala sekolah SMP Negeri 3 Singkawang, penetapan sasaran dan tujuan kurikulum berdasarkan visi dan misi SMP Negeri 3 Singkawang. Penetapan sasaran dan tujuan kurikulum dilakukan di awal tahun ajaran. Konsep sasaran dan tujuan kurikulum dibuat oleh kepala sekolah bersama waka kurikulum berdasarkan masukan serta pertimbangan dari tim pengembang kurikulum.

Pendapat kepala sekolah tersebut didukung oleh waka kurikulum SMP Negeri 3 Singkawang. Berdasarkan hasil wawancara dengan waka kurikulum SMP Negeri 3 Singkawang dalam menetapkan sasaran dan tujuan kurikulum disesuaikan dengan visi dan misi sekolah. Sasaran dan tujuan kurikulum dibuat oleh guru berdasarkan konsep yang telah ditetapkan kepala sekolah dan waka kurikulum, selanjutnya dikembangkan dan disetujui serta ditetapkan oleh kepala sekolah dan waka kurikulum beserta tim pengembang kurikulum.
Mengorganisasikan Materi dalam Pembelajaran

Berdasarkan hasil wawancara dengan waka kurikulum SMP Negeri 3 Singkawang, dalam mengorganisasikan materi pembelajaran, sekolah berpedoman pada panduan yang ditetapkan oleh pemerintah. Kumpulan materi-materi pembelajaran yang akan diberikan kepada siswa termuat dalam buku pelajaran. Dalam menggunakan buku pelajaran, sekolah menggunakan buku yang wajib yang sudah ditentukan oleh pemerintah. Selain buku wajib dari pemerintah, sekolah juga menggunakan buku yang dipilih oleh guru sebagai referensi untuk diajarkan kepada siswa.

Berdasarkan hasil wawancara dengan guru bahasa inggris, matematika, fisika, dan TIK, dalam mengorganisasikan materi pembelajaran, sekolah dalam mengorganisasikan materi dalam pembelajaran, mereka berpedoman pada panduan yang ditetapkan oleh pemerintah. Program pembelajaran Bahasa Inggris di SMP Negeri 3 Singkawang disusun berdasarkan hasil pertemuan para guru mata pelajaran Bahasa Inggris (MGMP) kota Singkawang setiap hari selasa selama 3 bulan. Hasil pertemuan tersebut ditindaklanjuti dengan pertemuan guru mata pelajaran Bahasa Inggris (MGMP) intern SMP Negeri 3 Singkawang setiap hari sabtu. Pertemuan guru mata pelajaran Bahasa Inggris tersebut menghasilkan program pembelajaran dalam bentuk silabus dan RPP yang diketahui dan disetujui oleh kepala sekolah. Khusus untuk mata pelajaran matematika, guru matematika telah mengikuti Diklat KTSP Nasional di Surabaya dan Bogor. Selanjutnya setiap hari sabtu, guru melakukan MGMP mata pelajaran matematika yang nantinya menghasilkan program pembelajaran yang diketahui dan disetujui oleh kepala sekolah. Khusus mata pelajaran IPA, materi pembelajaran disesuaikan dengan hasil pembahasan kelompok guru mata pelajaran IPA.

Berdasarkan pencermatan dokumen, yaitu pencermatan notulen rapat 
dinas SMP Negeri 3 Singkawang, pertemuan seluruh dewan guru dalam melakukan perencanaan kurikulum dilaksanakan pada hari Sabtu, tanggal 23 Juni 2012. Dalam notulen tersebut dijelaskan bahwa rapat tersebut dihadiri oleh 28 orang guru dengan agenda yang dibahas adalah perencanaan kurikulum, serta pembagian jam mengajar seluruh guru di SMP Negeri 3 Singkawang.

Beban belajar SMP Negeri 3 Singkawang merupakan sistem paket. 1 jam pelajaran (JP) terdiri atas 40 menit kegiatan tatap muka, 20 menit kegiatan penugasan terstruktur, dan 20 menit kegiatan mandiri tidak terstruktur. Dengan pengertian satu jam pelajaran tersebut dan mempertimbangkan waktu yang tersedia setiap minggunya, beban belajar siswa SMP Negeri 3 Singkawang berkisar 42 jam pembelajaran perminggu dengan Bahasa Inggris, IPA, dan Matematika masingmasing 6 jam pelajaran dan TIK-PTD 4 jam pelajaran.

Ketuntasan belajar adalah tingkat ketercapaian kompetensi setelah peserta didik mengikuti kegiatan pembelajaran. Sedangkan kriteria ketuntasan minimal (KKM) merupakan batas minimal pencapaian kompetensi pada setiap aspek penilaian mata pelajaran yang harus dikuasai oleh peserta didik. Siswa dengan nilai dibawah atau belum dapat mencapai batas KKM harus mengikuti program perbaikan (remedial) dan siswa yang telah mencapai atau melebihi nilai KKM dapat mengikuti program pengayaan (enrichment).

Menyiapkan Sarana dan Prasarana serta Media dalam Pembelajaran

Berdasarkan hasil wawancara dengan kepala sekolah SMP Negeri 3 Singkawang, dalam mempersiapkan sarana dan prasarana serta media pembelajaran, sekolah melakukan penyusunan rencana kerja sekolah. Melalui penyusunan rencana kerja sekolah, akan diketahui apa yang menjadi keperluan serta kebutuhan dari masingmasing guru mata pelajaran.

Dengan memperhatikan keperluan serta kebutuhan guru tersebut, kepala sekolah akan membuat skala prioritas.
Guru diminta untuk membuat proposal media, alat peraga apa saja yang mereka perlukan dalam proses pembelajaran kepada sekolah. Selanjutnya sekolah akan memberikan pertimbangan berdasarkan kondisi keuangan sekolah dan skala prioritas.

Hasil wawancara dengan waka kurikulum SMP Negeri 3 Singkawang, menyatakan bahwa secara umum sarana dan prasarana serta media dalam pembelajaran disiapkan oleh sekolah, misalnya LCD proyektor, software-software pembelajaran, kemudian laboratorium. Namun untuk media pembelajaran ada yang dibuat oleh guru sendiri, misalnya dalam mata pelajaran bahasa inggris.

\section{Menentukan Strategi Pembelajaran}

Berdasarkan hasil wawancara dengan kepala sekolah SMP Negeri 3 Singkawang, sekolah memberikan kesempatan seluas-luasnya kepada guru untuk mengembangkan strategi pembelajaran yang sesuai dengan karakteristik masing-masing mata pelajaran yang mereka ajarkan. Sekolah menekankan strategi pembelajaran menggunakan komputer karena setiap kelas di SMP Negeri 3 Singkawang sudah menggunakan LCD Proyektor.

Kepala sekolah menekankan konsep guru kreatif dalam strategi pembelajaran..

Guru sebagai fasilitator memberikan kesimpulan dan penguatan terhadap materi yang telah dibagikan oleh anak tersebut. Hal tersebut akan merangsang kreativitas anak lainnya untuk melakukan hal yang sama dan menjadi sumber belajar bagi siswa lainnya.

Hasil wawancara dengan waka kurikulum SMP Negeri 3 Singkawang, menyatakan bahwa untuk menentukan strategi pembelajaran, sekolah memberikan wewenang penuh pada guru dalam menentukan strategi pembelajaran yang mereka gunakan dalam pembelajaran. Sekolah hanya mengatur waktu/memberikan waktu pada guru dalam proses pembelajaran, namun dalam praktiknya di kelas, guru diberikan kebebasan penuh. 
Mempersiapkan Program Evaluasi

Berdasarkan hasil wawancara dengan kepala sekolah SMP Negeri 3 Singkawang, kepala sekolah melakukan jadwal pelaksanaan supervisi kurikulum. Perencanaan supervisi kurikulum dilaksanakan oleh kepala sekolah, wakil kepala sekolah, wakil kepala sekolah bidang kurikulum dan guru-guru senior yang akan menghasilkan instrumen supervisi kurikulum. Pembuatan perencanaan supervisi kurikulum dilaksanakan di setiap awal semester berdasarkan panduan-panduan dari Kementerian Pendidikan dan Kebudayaan. Kepala sekolah memberikan petunjuk serta format penilaian kepada guru yang akan disupervisi.

Hasil wawancara dengan waka kurikulum SMP Negeri 3 Singkawang menyatakan bahwa setiap bulan kepala sekolah melakukan supervisi kurikulum untuk memastikan apakah RPP yang dibuat oleh guru sudah dilaksanakan. Tim supervisi kurikulum terdiri dari kepala sekolah waka kurikulum dan guru senior.

Dalam melakukan evaluasi kurikulum, sekolah membuat jurnal kegiatan guru. Jurnal kegiatan guru merupakan catatan aktifitas yang dilakukan guru selama mengajar di kelas. Jurnal tersebut dibuat setiap hari, direkap per akhir semester, guru menyerahkan rekap tersebut kepada bagian kurikulum sebagai acuan untuk pengembangan kurikulum selanjutnya.

Sekolah melakukan evaluasi tahunan berdasarkan supervisi kepala sekolah dan jurnal kegiatan guru yang dilakukan di akhir tahun pelajaran sebelum memulai tahun ajaran baru. Semua guru diundang dalam pertemuan tahunan tersebut.

Format instrumen supervisi kurikulum berpedoman pada format supervisi kurikulum yang telah ditetapkan oleh pemerintah. Dalam melakukan perencanaan supervisi kurikulum, kepala sekolah lebih menekankan aspek pengalaman dalam mengajar dibandingkan dengan tingkat akademis guru.
Faktor-Faktor Penghambat dalam Perencanaan Kurikulum di SMP Negeri 3 Singkawang

\section{Faktor Guru}

Berdasarkan hasil wawancara dengan kepala sekolah SMP Negeri 3 Singkawang, hambatan terbesar dalam perencanaan kurikulum adalah kekurangpahaman guru karena sebagian besar guru di SMP Negeri 3 Singkawang adalah guru senior dimana mereka lamban dalam menginterpretasikan KTSP sesuai pedoman-pedoman dari pemerintah. Sebagai contoh pada saat guru-guru diberikan waktu khusus untuk memberikan masukan serta dokumen yang diperlukan sebagai perangkat kurikulum, guru sangat lamban dan sampai waktu yang ditentukan belum menyerahkan dokumen yang diperlukan

Ada permasalahan lain dimana guru yang latar belakang sarjana biologi saja, mengajar mata pelajaran fisika atau guru yang latar belakang sejarah saja namun harus harus mengajar mata pelajaran ekonomi karena kurikulum KTSP memberlakukan mata pelajaran IPA terpadu yang di dalamnya terdiri dari mata pelajaran biologi dan fisika, dan mata pelajaran IPS terpadu yang di dalamnya terdiri dari mata pelajaran ekonomi, sejarah dan geografi.

Hal tersebut didukung oleh hasil wawancara dengan waka kurikulum SMP Negeri 3 Singkawang yang menyatakan bahwa hambatan dalam perencanaan kurikulum berasal dari guru. Pemerintah sudah menetapkan pedoman penyusunan kurikulum. Namun ada beberapa guru senior kesulitan dalam mengembangkan perencanaan kurikulum.

\section{Faktor Sarana dan Prasarana}

Berdasarkan hasil wawancara dengan waka kurikulum SMP Negeri 3 Singkawang hambatan dalam sarana dan prasarana adalah SMP Negeri 3 Singkawang keterbatasan laboratorium yang dimiliki sekolah. Sekolah baru memiliki laboratorium Fisika, Bahasa, Biologi, dan kom- 
puter. Sekolah belum memiliki laboratorium matematika dan IPS.

\section{Faktor Biaya}

Berdasarkan hasil wawancara dengan kepala sekolah SMP Negeri 3 Singkawang SMP Negeri 3 Singkawang mengalami kendala dalam mendatangkan narasumber untuk memberikan penjelasan tentang perencanaan kurikulum secara khususnya. Kota Singkawang tidak memiliki universitas dan perguruan tinggi seperti kota Pontianak (ibukota provinsi) sehingga kesulitan dalam mendatangkan narasumber yang kompeten di bidang pendidikan khususnya perencanaan kurikulum.

Mendatangkan narasumber ke SMP Negeri 3 Singkawang diperlukan dana yang sangat besar. Selanjutnya melaksanakan atau mengirim guru mengikuti workshop, in house training untuk mening-katkan kompetensi guru SMP Negeri 3 Singkawang dalam perencanaan kurikulum khususnya diperlukan dana yang sangat besar.

Usaha SMP Negeri 3 Singkawang Mengatasi Hambatan dalam Perencanaan Kurikulum

\section{Faktor Guru}

Berdasarkan hasil wawancara dengan kepala sekolah SMP Negeri 3 Singkawang untuk mengatasi kendala dimana guru terutama guru senior kurang paham dalam menginteprasikan kurikulum sesuai dengan pedoman dari pemerintah, sekolah berinisiatif mengadakan in house training, mengadakan workshop dengan mendatangkan narasumber dari LPMP provinsi.

Sekolah mengadakan pelatihan dipimpin oleh kepala sekolah atau guru yang dianggap memiliki kemampuan lebih diantara guru-guru mata pelajaran yang terkait sesuai dengan bidang pelajaran mereka masing-masing. Hal ini lebih dikenal dengan MGMP Mandiri atau MGMP internal. Kegiatan MGMP Internal guru dilaksanakan setiap hari sabtu setelah proses belajar mengajar sudah berakhir. Setiap guru sesuai mata pelajaran yang mereka ajarkan masuk ke kelas, mem-bicarakan kesulitan-kesulitan yang diha-dapi dalam proses pembelajaran serta perencanaan untuk mengatasi kesulitan-kesulitan yang mereka hadapi.

Berdasarkan hasil wawancara dengan waka kurikulum SMP Negeri 3 Singkawang, untuk mengatasi masalah guru yang kesulitan mengembangkan perencanaan kurikulum, sekolah mengirim guru tersebut untuk mengikuti diklat. Sekolah terkadang diundang oleh dinas pendidikan untuk mengikuti diklat. Sekolah mengadakan workshop/pelatihan sendiri dengan mengundang narasumber dari LPMP. Kegiatan tersebut dilakukan di akhir-akhir semester genap untuk semua guru. Dilakukan di akhir semester genap sebagai persiapan untuk memasuki semester selanjutnya.

\section{Faktor Sarana dan Prasarana}

Berdasarkan hasil wawancara dengan kepala sekolah SMP Negeri 3 Singkawang, sekolah memiliki rencana untuk membangun laboratorium matematika dan laboratorium IPS di area kosong belakang sekolah. Berdasarkan hasil wawancara dengan waka kurikulum SMP Negeri 3 Singkawang, Untuk mengatasi masalah sarana dan prasarana sekolah melakukan moving class, kelas dijadikan laboratorium, namun tidak sepenuhnya.

\section{Faktor Biaya}

Berdasarkan hasil wawancara dengan kepala sekolah SMP Negeri 3 Singkawang, untuk mengatasi kendala pendanaan, sekolah mengembangkan kerja sama dengan komite sekolah dimana komite sekolah membangun kemitraan yang kuat dengan pihak Kementerian Pendidikan khususnya sehingga SMP Negeri 3 Singkawang mendapat perhatian yang lebih dari pemerintah dalam hal ini Kementerian Pendidikan Nasional sehingga memperoleh dana-dana yang dipergunakan untuk pembangunan sarana dan prasarana pendidikan di sekolah, seperti pembangunan laboratorium bahasa, komputer, pengadaan komputer dan dana tersebut juga dialokasikan untuk meningkatkan kualitas 
mengajar guru melalui pelatihan, workshop serta in house training bagi guru.

Hal-Hal Khusus yang Menjadi Kekhasan SMP Negeri 3 Singkawang dalam Perencanaan Kurikulum

\section{Analisis Lingkungan Strategis}

Berdasarkan hasil pencermatan dokumen yaitu dokumen RKS dan RKAS SMP Negeri 3 Singkawang Tahun 20102013, diperoleh informasi bahwa dalam melakukan penyusunan RKS dan RKAS, SMP Negeri 3 Singkawang terlebih dahulu melakukan kajian tentang kondisi sosial, ekonomi, politik, keamanan, kemajuan IPTEK, geografis, demografis, globalisasi serta regulasi. Seluruh aspek-aspek yang dikaji tersebut sangat mempengaruhi penyelengaraan proses pendidikan di SMP Negeri 3 Singkawang.

\section{Analisis Pendidikan Saat Ini dan Masa Depan}

Berdasarkan hasil pencermatan dokumen yaitu dokumen RKS dan RKAS SMP Negeri 3 Singkawang Tahun 20102013, diperoleh informasi bahwa SMP Negeri 3 Singkawang melakukan analisis pendidikan saat ini serta pendidikan masa depan. Kesenjangan kondisi pendidikan saat ini dengan kondisi pendidikan masa depan dinilai secara kuantitatif dalam bentuk persentase dan dideskripsikan sebagai tantangan nyata. Adapun aspekaspek dalam analisis pendidikan saat ini dan masa depan yaitu: mutu pendidikan, akses dan pemerataan pendidikan, efisiensi pendidikan, relevansi pendidikan, daya saing lulusan serta pencitraan publik.

Untuk menjawab tantangan tersebut yaitu mengurangi bahkan menghilangkan kesenjangan pendidikan saat ini dan masa depan diperlukan kebijakan-kebijakan dimana salah satunya adalah perencanaan kurikulum yang mampu mengakomodasi seluruh aspek-aspek dalam analisis pendidikan yaitu: mutu pendidikan, akses dan pemerataan pendidikan, efisiensi pendidikan, relevansi pendidikan, daya saing lulusan serta pencitraan publik. Perencanaan kurikulum di SMP Negeri 3
Singkawang berpedoman pada peningkatan aspek-aspek dalam pendidikan antara lain: mutu pendidikan, akses dan pemerataan pendidikan, efisiensi pendidikan, relevansi pendidikan, daya saing lulusan serta pencitraan publik.

Program Strategis dan Strategi Pelaksanaan/Pencapaian

Berdasarkan hasil pencermatan dokumen yaitu dokumen RKS dan RKAS SMP Negeri 3 Singkawang Tahun 20102013, diperoleh informasi bahwa SMP Negeri 3 Singkawang telah menetapkan program strategis dan strategi pelaksanaan/pencapaian yang berkaitan dengan perencanaan kurikulum.

Program Strategis yang berkaitan dengan perencanaan kurikulum di SMP Negeri 3 Singkawang adalah sebagai berikut:

\section{Standar Isi}

Pengembangan KTSP, Pengembangan Silabus, Pengembangan RPP, Pengembangan SK, KD dan Indikator, Pengembangan bahan ajar, modul, buku

\section{Standar Proses}

Pengembangan dan inovasi metode pembelajaran, Pengembangan dan inovasi bahan pembelajaran, Pengembangan dan inovasi sumber pembelajaran, Pengembangan dan inovasi model pengelolaan kelas, Peningkatan pelaksanaan penilaian pembelajaran, Peningkatan pengawasan proses pembelajaran

\section{Standar Kompetensi Lulusan}

Peningkatan prestasi bidang akademik, Peningkatan prestasi bidang non akademik, Peningkatan jumlah kelulusan , Peningkatan jumlah siswa yang melanjutkan studi ke sekolah yang lebih tinggi

Strategi Pelaksanaan/Pencapaian yang berkaitan dengan perencanaan kurikulum di SMP Negeri 3 Singkawang adalah sebagai berikut: Standar Isi 
Pengembangan KTSP

Sosialisasi kepada seluruh stakeholder tentang KTSP, Pelatihan/Workshop dengan mengundang pakar KTSP, Membentuk tim Pengembang KTSP, Pengembangan silabus, Mengaktifkan team teaching dan mentoring tiap mata pelajaran di sekolah, Meningkatkan kegiatan MGMP sekolah, Studi banding ke sekolah-sekolah di dalam dan luar negeri, Mengikutsertakan guru dalam kegiatan seminar/ workshop KTSP , Dokumentasi hasil

\section{Pengembangan RPP}

Menganalisa KD, SK dan Materi Pokok, IHT dengan memanfaatkan guru inti dan tim pengembang kurikulum sekolah, studi banding ke sekolah-sekolah dalam dan luar negeri, dokumentasi hasil

\section{Pengembangan SK, KD dan Indikator}

Menganalisa materi pokok, Meningkatkan kerja sama dengan jejaring kurikulum tingkat provinsi, Pengembangan bahan ajar modul, buku, Membangun jejaring dengan sekolah di dalam dan luar negeri, Mengadaptasi atau mengadopsi bahan ajar, modul dan buku dari sekolah dalam dan luar negeri

\section{Standar Proses}

- Pengembangan dan inovasi metode pembelajaran

Workshop inovasi metode pembelajaran, Penerapan metode dan strategi pembelajaran CTL, Problem Solving, Mastery Learning dan pembelajaran bermakna

- Pengembangan dan inovasi bahan pembelajaran

Mengidentifikasi aspek-aspek dalam SK dan KD, Memilih materi pembelajaran yang sesuai dengan SK dan KD, Memilih sumber bahan ajar yang sesuai dengan kurikulum

- Pengembangan dan inovasi sumber pembelajaran

Meningkatkan manajemen penggunaan Lab. IPA, Bahasa dan Komputer, Meningkatkan manajemen pengelolaan perpustakaan
Meningkatkan kemampuan menggunakan Lab IPA, Bahasa dan Komputer dalam proses pembelajaran, Mendatangkan Native Speaker, Seminar "Pengembangan dan Inovasi Sumber Pembelajaran"

- Pengembangan dan inovasi model pengelolaan kelas

Meningkatkan kemampuan wali kelas dalam mengelola tata ruang kelas, Menciptakan iklim pembelajaran yang kondusif, kreatif dan menyenangkan.

- Peningkatan pelaksanaan penilaian pembelajaran

Mengembangkan berbagai teknik penilaian, Mengevaluasi penerapan teknik penilaian, Memberi bimbingan secara khusus bagi kelompok peserta didik yang berprestasi atau yang bermasalah, Peningkatan pengawasan proses pembelajaran, Melaksanakan supervisi kelas secara konsisten dan terprogram, Melakukan evaluasi program pembelajaran

\section{Standar Kompetensi Lulusan}

Peningkatan prestasi bidang akademik

Mengadakan try out, Mengadakan pedalaman materi untuk semua siswa, Melaksanakan pogram remedial dan pengayaan, Mengikutsertakan siswa dalam lomba-lomba akademik, Mengadakan program cerdas cermat secara berkala dan terprogram, Meningkatkan kegiatan English Club dan Math Club

Peningkatan prestasi bidang nonakademik

Meningkatkan kualitas kegiatan ekstrakurikuler, Meningkatkan pembinaan kegiatan ekstrakurikuler, Penyusunan tim inti, Meningkatkan kualitas pelayanan Bimbingan dan Konseling, Mengikutsertakan siswa dalam lomba-lomba nonakademik

Peningkatan jumlah kelulusan

Membuat program standar kelulusan, Mensosialisasikan standar kelulusan pada siswa, orang tua 
siswa/wali siswa, Melengkapi bukubuku referensi pembelajaran, Pendalaman materi khusus materi UN,

Peningkatan jumlah siswa yang melanjutkan studi ke sekolah yang lebih tinggi

Sosialisasi SMA/SMK, Kunjungan ke sekolah-sekolah, Mengikuti try out.

Kebijakan SMP Negeri 3 Singkawang dalam menetapkan program strategis dan strategi pelaksanaan/pencapaian yang berkaitan dengan perencanaan kurikulum berimplikasi pada pelaksanaan kurikulum yang jelas dan terarah sehingga meningkatkan prestasi siswa secara khususnya.

\section{Penambahan Jam Pelajaran}

Berdasarkan hasil wawancara dengan Waka Kurikulum SMP Negeri 3 Singkawang, sekolah memberikan perhatian khusus kepada 5 mata pelajaran yaitu Bahasa inggris, fisika, biologi, matematika, TIK karena terjadi penambahan jam pelajaran. Untuk mata pelajaran matematika, sekolah memberikan penambahan jam dari 5 jam menjadi 6 jam per minggu. Untuk mata pelajaran biologi dan fisika, sekolah memberikan penambahan jam pelajaran dari 5 jam menjadi 6 jam pelajaran per minggu. Selanjutnya, untuk mata pelajaran TIK, sekolah memberikan penambahan jam pelajaran dari 2 jam menjadi 4 jam per minggu.

Pendapat Waka Kurikulum SMP Negeri 3 Singkawang tersebut diperkuat dengan hasil pencermatan dokumen yaitu notulen Rapat Dinas SMP Negeri 3 Singkawang pada hari Sabtu, tanggal 23 Juni 2012. Pertemuan rapat tersebut dihadiri oleh 28 orang guru dengan salah satu hasil rapat yaitu penambahan jam pelajaran untuk mata pelajaran bahasa inggris, fisika, biologi, matematika dan TIK.

\section{Program Remidial dan Pengayaan}

Berdasarkan hasil wawancara dengan guru bahasa inggris, fisika, biologi serta matematika diperoleh informasi bahwa kegiatan belajar mengajar di SMP
Negeri 3 Singkawang dimulai dari pukul 07.00 WIB sampai dengan pukul 12.00 WIB. Karena pada saat itu SMP Negeri 3 Singkawang masih berstatus sebagai sekolah RSBI, seluruh proses belajar mengajar pada pukul 07.00-12.00 menggunakan bahasa pengantar bahasa Inggris kecuali untuk mata pelajaran Bahasa Indonesia.

Pada pukul 12.00 sampai dengan pukul 13.00 merupakan jam istirahat dimana seluruh siswa menggunakan waktu tersebut untuk makan siang serta sholat untuk siswa yang beragama muslim. Pada jam istirahat tersebut, siswa tidak diperkenankan untuk keluar dari sekolah, seluruh perbekalan untuk makan siang dipersiapkan dari rumah oleh masing-masing orang tua siswa, dan diberikan kepada siswa pada jam istirahat.

Selanjutnya pada pukul 13.00 sampai dengan pukul 16.00 dilakukan penguatan terhadap materi yang diberikan kepada siswa di pagi hari dan menggunakan bahsa pengantar bahasa indonesia, pengayaan bagi siswa yang telah mencapai atau melebihi nilai kriteria ketuntas-an minimal serta remidial untuk mengakomodasi siswa dengan nilai di bawah atau belum dapat mencapai batas kriteria ketuntasan minimal.

Berdasarkan hasil pencermatan dokumen kurikulum SMP Negeri 3 Singkawang, SMP Negeri 3 Singkawang memiliki program remidial untuk mengakomodasi siswa dengan nilai di bawah atau belum dapat mencapai batas kriteria ketuntasan minimal dan siswa yang telah mencapai atau melebihi nilai kriteria ketuntasan minimal dapat mengikuti program pengayaan. Fakta tersebut didukung oleh hasil wawancara dengan guru bahasa inggris, fisika, biologi dan matematika yang menyatakan bahwa untuk mata pelajaran yang mereka ajarkan ada program remedial dan pengayaan. Secara khusus dijelaskan bahwa program remidial dilaksanakan sesudah pulang sekolah sesuai dengan jadwal yang sudah ditentukan.

Hasil pencermatan dokumen yaitu dokumen RKS dan serta notulen Rapat Dinas SMP Negeri 3 Singkawang hari 
Sabtu tanggal 23 Juni 2013 menyatakan bahwa program remidial yang akan dilakukan guru mata pelajaran terlebih dahulu diajukan kepada kepala sekolah.

Berdasarkan hasil wawancara dengan guru bahasa inggris, fisika, biologi serta matematika diperoleh informasi bahwa program pengayaan dilaksanakan setelah pulang sekolah sesuai dengan jadwal yang sudah ditentukan. Program pengayaan juga mengakomodasi siswasiswa yang berprestasi dalam bidang mata pelajaran tertentu untuk berlatih soal-soal sehingga mempersiapkan mereka sedini mungkin untuk berprestasi dalam kegiatan akademik.

\section{Kegiatan Pengembangan Diri}

Berdasarkan hasil pencermatan dokumen SMP Negeri 3 Singkawang, yaitu profil SMP Negeri 3 Singkawang kegiatan pengembangan diri di SMP Negeri 3 Singkawang antara lain: sepakbola, voli, basket, karate, pramuka, palang merah remaja. Hasil pencermatan dokumen yaitu notulen Rapat Dinas SMP Negeri 3 Singkawang hari Sabtu tanggal 23 Juni 2013 menyatakan bahwa kegiatan kegiatan pengembangan diri dilaksanakan setiap hari Sabtu selama 2 jam pelajaran. Dalam notulen rapat tersebut seluruh guru SMP Negeri 3 Singkawang diharapkan terlibat aktif dalam kegiatan pengembangan diri.

Kegiatan ekstrakurikuler di SMP Negeri 3 Singkawang yang beraneka ragam mampu mengakomodasi seluruh karakteristik peserta didik sehingga akan meningkatkan potensi, kecerdasan, dan minat sesuai dengan tingkat perkembangan dan kemampuan peserta didik. Keterlibatan semua guru dalam kegiatan ekstrakurikuler akan meningkatkan iklim sekolah yang kondusif dan rasa kekeluargaan yang tinggi diantara seluruh warga sekolah sehingga berpotensi untuk meningkatkan prestasi siswa khususnya dalam bidang nonakademik.

\section{Simpulan}

Perencanaan kurikulum SMP Negeri 3 Singkawang dapat disimpulkan sebagai berikut:

Perencanaan kurikulum yang dilakukan SMP Negeri 3 Singkawang sehingga sesuai dengan karakteristik sekolah dilakukan oleh tim pengembang kurukulum SMP Negeri 3 Singkawang berpedoman pada panduan penyusunan kurikulum dari pemerintah.

Perencanaan komponen-komponen kurikulum di SMP Negeri 3 adalah sebagai berikut:

Dalam menetapkan sasaran dan tujuan kurikulum berdasarkan visi dan misi SMP Negeri 3 Singkawang. Konsep sasaran dan tujuan kurikulum dibuat oleh kepala sekolah bersama waka kurikulum berdasarkan masukan serta pertimbangan dari tim pengembang kurikulum

Dalam mengorganisasikan materi pembelajaran, sekolah berpedoman pada panduan yang ditetapkan oleh pemerintah. Materi pembelajaran disusun berdasarkan hasil pertemuan MGMP kota Singkawang dan MGMP sekolah. Pertemuan tersebut menghasilkan materi pembelajaran dalam bentuk silabus dan RPP yang diketahui dan disetujui oleh kepala sekolah.

Dalam mempersiapkan sarana dan prasarana serta media pembelajaran, SMP Negeri 3 Singkawang melakukan penyusunan rencana kerja sekolah. Melalui penyusunan rencana kerja sekolah, akan diketahui sarana, prasarana serta apa yang menjadi keperluan serta kebutuhan dari masing-masing guru mata pelajaran.

SMP Negeri 3 Singkawang memberikan kesempatan seluas-luasnya kepada guru untuk mengembangkan strategi pembelajaran yang sesuai dengan karakteristik masing-masing mata pelajaran yang mereka ajarkan.

Dalam mempersiapkan program evaluasi kurikulum. SMP Negeri 3 Singkawang mengembangkan instrumen supervisi kurikulum dan mengembangkan jurnal kegiatan guru. 
Hambatan dalam perencanaan kurikulum di SMP Negeri 3 adalah kekurangpahaman guru terutama guru senior dalam mengintrepetasikan kurukulum sesuai pedoman-pedoman dari pemerintah.

Usaha SMP Negeri 3 untuk mengatasi hambatan dalam perencanaan kurikulum adalah mengadakan in house training secara khususnya, mengadakan workshop dengan mendatangkan narasumber dari LPMP provinsi.

Hal-hal khusus yang menjadi kekhasan SMP Negeri 3 Singkawang dalam perencanaan kurikulum antara lain:

Analisis Lingkungan Strategis, Analisis Pendidikan Saat Ini dan Masa Depan, Program Strategis dan Strategi Pelaksanaan/Pencapaian, Penambahan Jam Pelajaran, Program Remidial dan Pengayaan, Kegiatan Pengembangan Diri

Implikasi

Berdasarkan penelitian di lapangan, peneliti menemukan beberapa hal yang perlu mendapat perhatian dalam proses perencanaan kurikulum di SMP Negeri 3 Singkawang. Hal-hal yang perlu mendapat perhatian tersebut antara lain:

Perencanaan kurikulum yang dilakukan SMP Negeri 3 Singkawang sehingga sesuai dengan karakteristik sekolah dilakukan oleh tim pengembang kurikulum SMP Negeri 3 Singkawang berpedoman pada panduan penyusunan kurikulum dari pemerintah. Tim pe-ngembang kurikulum SMP Negeri 3 Singkawang terdiri dari kepala sekolah, wakil kepala sekolah, waka kurikulum, komite sekolah, beberapa guru mata pelajaran.

Hal-hal khusus yang menjadi kekhasan SMP Negeri 3 Singkawang dalam perencanaa kurikulum antara lain: Analisis Lingkungan Strategis, Analisis Pendidikan Saat Ini dan Masa Depan, Program Strategis dan Strategi Pelaksanaan/Pencapaian, Penambahan Jam Pelajaran, Program Remidial dan Pengayaan, Kegiatan Pengembangan Diri

Kebijakan SMP Negeri 3 Singkawang mengembangkan perencanaan kuri- kulum dilakukan oleh tim pengembang kurikulum dan hal-hal khusus yang menjadi kekhasan SMP Negeri 3 Singkawang dalam perencanaan kurikulum tersebut dapat dijadikan model bagi sekolah lain untuk mengembangkan perencanaan kurikulum yang baik sehingga menghasilkan pendidikan yang berkualitas yang mendorong keberhasilan sekolah dan prestasi siswa.

\section{Keterbatasan Penelitian}

Penelitian ini menggunakan definisi penelitian yang bersifat umum sehingga mempunyai pengertian yang sangat luas. Hal tersebut mengakibatkan hasil penelitian dan pembahasan kurang bersifat mendalam. Pembahasan hanya mengungkap gambaran umum permasalahan yang ingin diungkap. Keterbatasan lainnya adalah keterbatasan peneliti sendiri termasuk pemahaman terhadapobjek yang sedang diteliti.

\section{Saran}

Demi memanfaatkan hasil penelitian sebagai informasi bagaimana perencanaan kurikulum di SMP Negeri 3 Singkawang, maka peneliti memberikan saransaran khusus bagi SMP Negeri 3 Singkawang. Saran-saran tersebut adalah sebagai berikut:

1. Lebih mempersiapkan sumber daya manusia, terutama guru. Pihak sekolah dapat lebih intensif lagi mengikutsertakan guru untuk mengikuti kegiatan diklat, workshop yang secara khusus berkaitan dengan perencanaan kurikulum. Sekolah lebih lagi mengoptimalkan in house training dan MGMP internal guru mata pelajaran secara rutin untuk meningkatkan kemampuan guru secara khusus dalam mengembangkan perencanaan kurikulum.

2. Memberikan masukan kepada Dinas Pendidikan kota Singkawang khususnya untuk mengadakan secara rutin dan intensif kegiatan diklat, workshop yang berkaitan dengan perencanaan 
kurikulum khususnya untuk meningkatkan kemampuan guru dalam melakukan perencanaan kurikulum di kota Singkawang.

\section{Daftar Pustaka}

Aly, Abdullah. (2011). Pendidikan islam multikultural di pesantren. Yogyakarta: Pustaka Pelajar.

Beane, J.A. (1986). Curriculum planning and development. New York: Allyn and Bacon INC.

Brady, L. (1992). Curriculum development. Sydney: Prentice Hall A Division of Simon \& Schuster.

BSNP. (2006). Panduan penyusunan kurikulum tingkat satuan pendidikan jenjang pendidikan dasar dan menengah.

Depdiknas. (2003). Undang-Undang RI No. 20 Tahun 2003 tentang Sistem Pendidikan Nasional.

Galtthorn, A.A. \& J.M. Jailall. (2009). The principal as curriculum leader (3 ${ }^{\text {rd }}$ edition). California. Corwin Press.

Hartati Sukirman dkk. (1998). Administrasi dan supervisi pendidikan. Yogyakarta: AP FIP IKIP Yogyakarta.

Jackson, P.W. (ed). (1992). Handbook of research and curriculum. New York: Mac Millan Publishing Company.

McMillan, J.H. \& Sally Schumacher. (2010). Research in education. New Jersey: Pearson Education Inc.

Law, E., Galton, M. \& Wan, S. (2010). Educational management administration $\mathcal{E}$ leadership: distributed curriculum leadership in action: a hongkong case study. Journal of British Educational Leadership, Management
\& Administration Society. Vol 38, No 3, pp. 286.

Miles, M.B. \& Huberman, A.M. (1985). Qualitative data analysis. London: Sage Publications.

Muhaimin, Sutiah \& Prabowo. (2008). Pengembangan model kurikulum tingkat satuan pendidikan pada sekolah dan madrasah. Jakarta: PT Raja Grafindo Persada.

Mohammad Ansyar. (1989). Dasar-dasar pengembangan kurikulum. Jakarta: Depdikbud.

Muhammad Nuh. (7 Maret 2013). Kurikulum 2013. Diambil pada tanggal 3 Juni 2013, dari http://kemdikbud. go.id/kemdikbud/artikelmendikbud-kurikulum2013.

Nana Syaodih Sukmadinata. (2005). Pengembangan kurikulum. Bandung: Remaja Rosdakarya.

Nasution, S. (2001). Asas-asas kurikulum. Jakarta: Bumi Aksara.

Ngalim Purwanto. (2010). Administrasi dan supervisi pendidikan. Bandung; Remaja Rosdakarya.

Oemar Hamalik. (2006). Manajemen pengembangan kurikulum. Bandung: Remaja Rosdakarya.

Oliva,P.F. (1992). Developing the curriculum. New York: Haper Colling Publishers.

Ornestin, A.C. \& Lunnenburg, F.C. (2000). Educational administration concepts and practices. New York: Wadswerth Thoson.

Wina Sanjaya. (2010). Kurikulum dan pembelajaran. Jakarta: Kencana Prenada Media Group. 